Primljen / Received: 16.11.2016. Ispravljen / Corrected: 24.2.2017.

Prihvaćen / Accepted: 28.3.2017. Dostupno online / Available online: 10.5.2017.

\section{New design procedure for four-leg channelized intersections}

Authors:

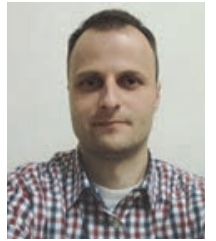

Assist.Prof. Ivica Stančerić, PhD. CE

University of Zagreb

Faculty of Civil Engineering

istanceric@grad.hr

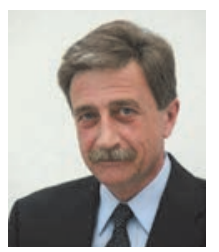

Prof. Željko Korlaet, PhD. CE

University of Zagreb

Faculty of Civil Engineering

zeljko.korlaet@grad.hr

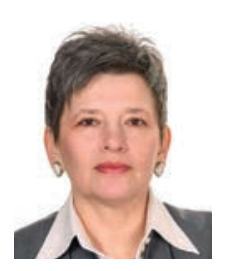

Prof. Vesna Dragčević, PhD. CE

University of Zagreb

Faculty of Civil Engineering

vesnad@grad.hr

\section{Ivica Stančerić, Željko Korlaet, Vesna Dragčević}

Original scientific paper

\section{New design procedure for four-leg channelized intersections}

The design and possible simplifications of four-leg channelized intersections are analysed in the paper. The research resulted in a new simpler approach in which all intersection elements are properly formed from the very beginning, so that the need for the swept path analysis and redefining of intersection elements is rendered superfluous. New procedures for the design of four-leg channelized intersections for the 60 to 90 degree intersection angles, and for semi-trailer trucks $16.5 \mathrm{~m}$ in length, are presented.

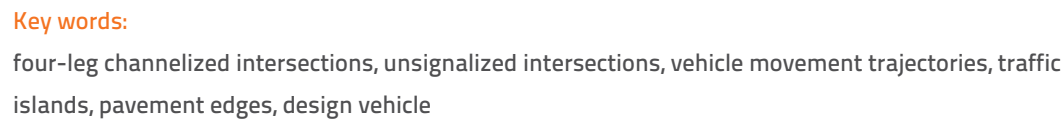

Izvorni znanstveni rad

\section{Ivica Stančerić, Željko Korlaet, Vesna Dragčević}

\section{Novi postupak oblikovanja četverokrakih kanaliziranih raskrižja}

U radu se istražuje projektiranje kanaliziranih četverokrakih raskrižja i moguća pojednostaljenja. Provedeno je istraživanje rezultiralo novim i jednostavnijim pristupom u kojem su svi elementi raskrižja pravilno oblikovani od samog početka, tako da je potreba za kontrolom provoznosti i redefiniranjem elemenata raskrižja postala suvišna. Prikazani novi postupci projektiranja četverokrakih kanaliziranih raskrižja za kutove presijecanja osi od 60 do $90^{\circ}$ za tegljač s poluprikolicom duljine $16.5 \mathrm{~m}$.

Ključne riječi:

četverokraka kanalizirana raskrižja, nesemaforizirana raskrižja, trajektorije kretanja vozila, prometni otoci, rubovi kolnika, mjerodavno vozilo

Ivica Stančerić, Željko Korlaet, Vesna Dragčević

Wissenschaftlicher Originalbeitrag

\section{Neues Verfahren zum Entwurf kanalisierter Vierfach-Kreuzungen}

In dieser Arbeit wird die Projektierung kanalisierter Vierfach-Kreuzungen und möglicher Vereinfachungen untersucht. Die durchgeführten Untersuchungen resultierten in einem neuen und einfacheren Verfahren, bei dem alle Elemente der Kreuzung von Anfang an gleichmäßig ausgebildet werden, so dass der Bedarf an Verkehrsflusskontrollen und nachträglichen Anpassungen einzelner Elemente der Kreuzung entfällt. Die dargestellten neuen Verfahren für den Entwurf von VierfachKreuzungen sind bei Achsenschnittwinkeln zwischen 60 und $90^{\circ}$ für 16,5 m lange Sattelzüge anwendbar.

\section{Schlüsselwörter:}

kanalisierte Vierfach-Kreuzungen, ampellose Kreuzungen, Fahrzeug-Fahrwege, Verkehrsinseln, Fahrbahnränder, maßgebendes Fahrzeug 


\section{Introduction}

Safety, smooth traffic flow, and rational use of space, are the primary goals in the design of roads and intersections. In terms of safety, traffic flows at at-grade intersections differ significantly from traffic flows on open roads due to the difficulty and number of traffic operations that have to be made on these intersections. Merging, diverging, interweaving and intersecting of traffic flows makes such locations potentially dangerous and susceptible to traffic accidents [1, 2]. Measures recommended for curbing traffic accidents at intersections usually include: location selection, adequate sight distance, channelizing of traffic flows with additional turning lanes and channelizing islands, reconstruction of intersection axes at intersections with skew angles, driving speed reduction, and placing adequate traffic signs and markings [1-3].

In the sphere of traffic safety at intersections, many studies have focused on the behaviour of elderly drivers at intersections [4-8] since elderly drivers, due to their reduced physical, perceptive and cognitive abilities, represent a potential danger for themselves and other drivers. However, the results of these studies offer only general recommendations and measures for improving traffic safety at intersections, and provide no specifically developed practical examples.

Over the past decade, an insignificant number of relevant scientific papers has been written about the design of four-leg at-grade intersections. Relevant recent scientific papers only deal with the design of roundabouts [9] or with the design of a single intersection element, such as the design of the right turn roadway edge $[10,11]$, design of left-turn lanes $[12,13]$ and design of right-turn lanes [14]. The usual present-day design procedure for the four-leg at-grade intersections on which Croatian [15], relevant European [16-18], and American design guidelines
[19] are based, involves separate design of each intersection design element and integration of these elements into the civil engineering design, which is followed by the swept path analysis with the design vehicle, and by correction of inadequately shaped elements (axes alignment, roadway edges, traffic islands, and "stop line" positions) (Figure 1a).

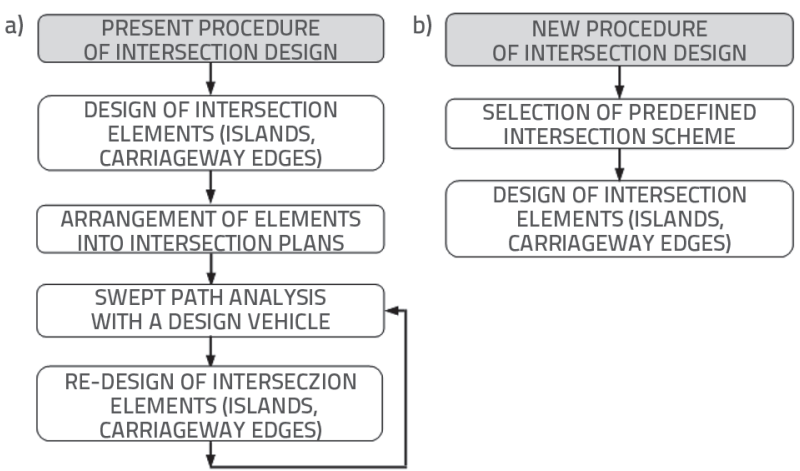

Figure 1. a) Current intersection design procedure; b) new intersection design procedure

Such an approach is applicable to some extent to the design of threeleg intersections (where redesigning of wrongly designed elements is not often necessary) since the mentioned guidelines are usually intended for their design. In the design of channelized (unsignalized) four-leg intersections such an approach - with an exception of the right intersection angle - usually results in significant alterations of the initially defined intersection. Some of that can be seen in the example of the intersection shown in Figure 2, designed according to Croatian standards [15] and German guidelines [16] for the intersection angle of $75^{\circ}$. At that intersection, the axes of secondary roads must be situated at a certain distance away from the intersection, so that vehicles (that are passing straight through

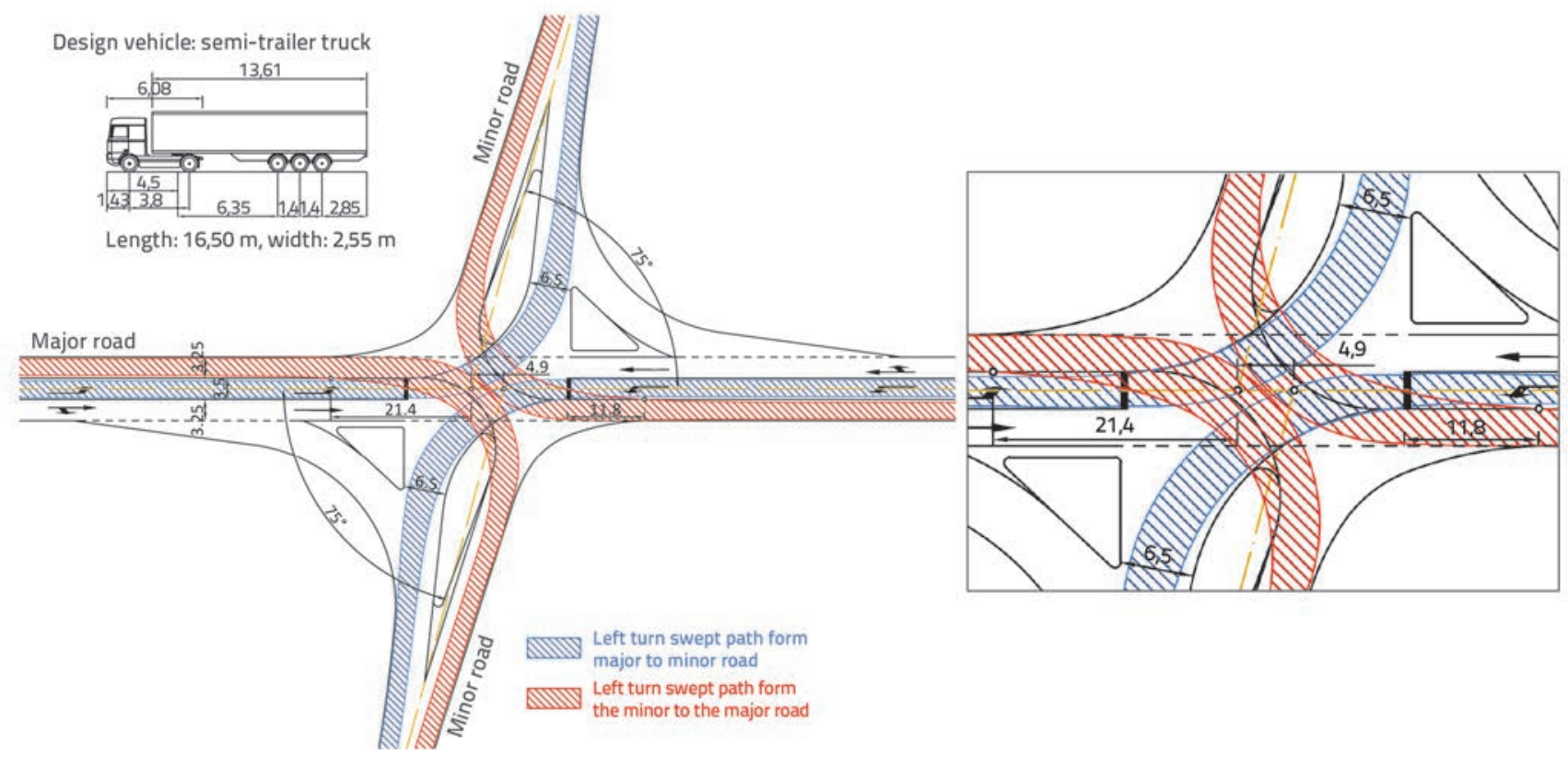

Figure 2. Swept path analysis and minor road axes realignment at channelized four-leg intersection designed according to standard [15] and guidelines [16] for the intersection angle of $75^{\circ}$ 
the intersection) do not collide with islands. Thus, instead of one minor road axis, two must be provided, which means that these axes have to be adjusted at some point to the original axis of the secondary road. In addition, vehicles making a left turn (from minor road to major road) have to go over the island and the stop line in order to pass through intersection without collision. This example of intersection (Figure 2) shows that significant alterations must be made to design elements and that these alterations are mainly due to the fact that at four-leg channelized intersections special attention should be paid to an undisturbed passage of vehicles through the intersection, and to vehicles turning left from the secondary road to access the major road.

At four-leg intersections with skewed angles (smaller than $\approx 70^{\circ}$ and bigger than $\approx 110^{\circ}$ ), the minor road axis must be realigned to ensure better visibility from vehicles [20-23]. Design guidelines $[16,19]$ offer a variety of ways for realigning minor road axes and defining design elements, but fail to provide detailed instructions as to their arrangement and incorporation into a four-leg intersection plan (Figure 3). The realignment of a minor road axis implies a series of additional problems in terms of defining intersection elements and managing traffic flows, and resorting to additional land purchase.

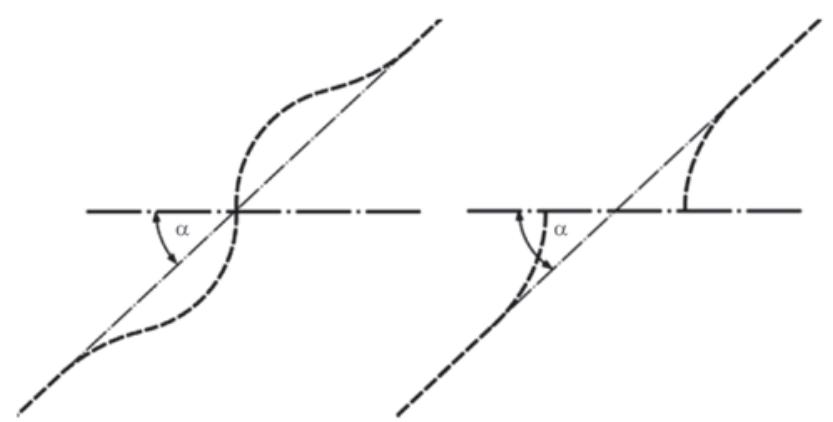

Figure 3. Different ways of minor road realignment at intersections with skewed intersection angles [16]

The above described issue was a motivation for a systematic research aimed at defining a new design procedure (Figure 1b) that would simplify and accelerate design of channelized (unsignalized) four-leg intersections and meet the designers' requirements for a greater reliability and efficiency in solving everyday tasks. The research is based on simulation of design vehicle movement trajectories, i.e. on the swept path analysis of theoretical intersection scenarios. It was conducted in a such a way to exclude, as much as possible, the need to correct inadequately designed elements and to proceed to subsequent swept path analysis. Due to large scope of the research and this paper's space constraints, solutions provided in this paper will be limited to intersection angles ranging from 60 to $90^{\circ}$, and to the analysis involving a $16.5 \mathrm{~m}$ long semi-trailer truck.

\section{Methodology}

The development of software for the swept path analysis (Auto track, Vehicle tracking, AutoTURN) enabled easier and faster drawing of vehicle movement trajectories, and establishment of a new procedure for designing intersections for the selected design vehicle. The basic prerequisite for the application of such software programs is their reliability.

In this paper, two computer programs are used as user applications in AutoCAD for the purpose of swept path analysis: AutoTrack and GF (developed at the Faculty of Civil Engineering of the University of Zagreb). The reliability of these programs was verified against experimental tests of vehicle movement on the polygon $[24,25]$. Test results $[24,25]$ showed that the departure from really measured values remains within the limits of accuracy of road pavement construction, and that the software programs are suitable for research involving accurate drawing of vehicle movement trajectories.

Other pre-research visibility tests from vehicle [23] were performed in order to determine the minimum allowable intersection angle up to which it is possible to keep the minor road axis in its original direction, since previous research [20-22] has revealed a problem of insufficient visibility from the vehicle at intersections with intersection angles smaller than $70^{\circ}$. The study presented in [23] was conducted on a four-leg intersection with three lanes on the major road (the central lane was for the left turn) taking into consideration physical limitations (head turn) [26] as well as the visual ability of the driver (field of vision) according to the EU Commission Directive 2009/113/EC [27]. Test results [23] show that intersection angles should be limited to at least $60^{\circ}$ for vehicle speed of up to $80 \mathrm{~km} / \mathrm{h}$ on a major road. Thus, the angle of $60^{\circ}$ was adopted as the initial angle in the development of the new intersection design procedure in which the minor road axis is maintained in the original direction.

\section{Research}

The research aimed at defining the new design procedure for channelized at-grade four-leg intersections (Figure 1.b) started with finding an intersection scheme in which all the intersection elements could be designed, for different intersection angles and without the need for an additional swept path analysis.

Tests started by drawing numerous $(1,240)$ theoretical intersection schemes (Figure 4), which were designed based on the following criteria:

- intersection angles between major and minor road axes $60 \leq$ $\alpha \leq 90^{\circ}\left(\operatorname{step} 5^{\circ}\right)$,

- three lanes (two for the through-traffic and one for the left turn traffic) on the major road, from 3.0 to $3.5 \mathrm{~m}$ in width,

- two lanes on the minor road, $3.0 \mathrm{~m}$ in width,

- right access lane on the minor road, $3.5 \mathrm{~m}$ in width,

- access lanes on the minor road were tapered to enable central-island construction $\left(A_{1,2}=3.0-8.0 \mathrm{~m}\right.$ and $B=40.0$ $-60.0 \mathrm{~m})$,

- through-traffic lanes were tapered on the major road at rate $1: 15$ and at various distances from axes intersection ( $C$ = $40.0-60.0 \mathrm{~m})$.

The research was conducted on such a considerable number of intersection schemes because the intention was to find out 


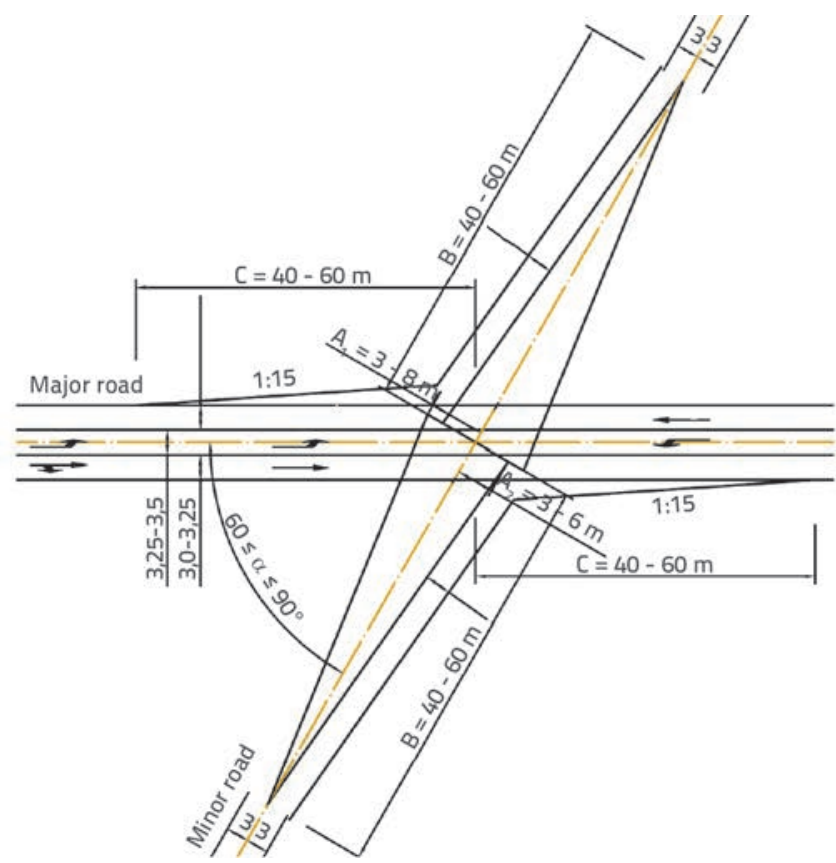

Figure 4. Initial schemes with steering paths and lateral safety distances

which intersection offers shorter distance between "stop lines" and axes intersection point, and which scheme offers shorter distance between the tip of the nose of the central channelizing island and through lane edge on the major road laccording to Croatian standard [15] and German guidelines [16], the nose offset should vary from 2.0 to $4.0(5.0) \mathrm{m}$ so that a smooth passage of opposing vehicles making left turn can be ensured). On all these intersection schemes, right and left turn swept paths were drawn for the design vehicle, i.e. for the $16.5 \mathrm{~m}$ long semi-trailer truck (Figure 5). These dimensions are in accordance with the EU Commission Directive 2002/7/EC [28], respecting the following criteria relevant for the safe and undisturbed traffic flow at intersections:

- steering paths for the front of the body of turning vehicles were designed from in and out straight lines and circular arc between them, with the applied radius being equal to or greater than $12.5 \mathrm{~m}$ (Figure 4) [28],

- minimum safety lateral distances were $0.25 \mathrm{~m}$ along the carriageway/lane edge (Figure 4),

- safety distance between passing vehicles that turn left from the major road to the minor road was at least $1.0 \mathrm{~m}$,

- safety distance between passing vehicles that turn left from the minor road to the major road varied from 0.0 to $1.0 \mathrm{~m}$,

- turning manoeuvres were drawn without encroaching into the lanes intended for other vehicles and without crossing solid lines of horizontal signalization.

The swept path analysis of the design vehicle was followed by the design of central and triangle channelizing islands on the minor road (Figure 5). Central islands were designed between tapered lanes and swept paths for the left turn, with the minimum lateral safety distance of $0.5 \mathrm{~m}$. Triangular islands

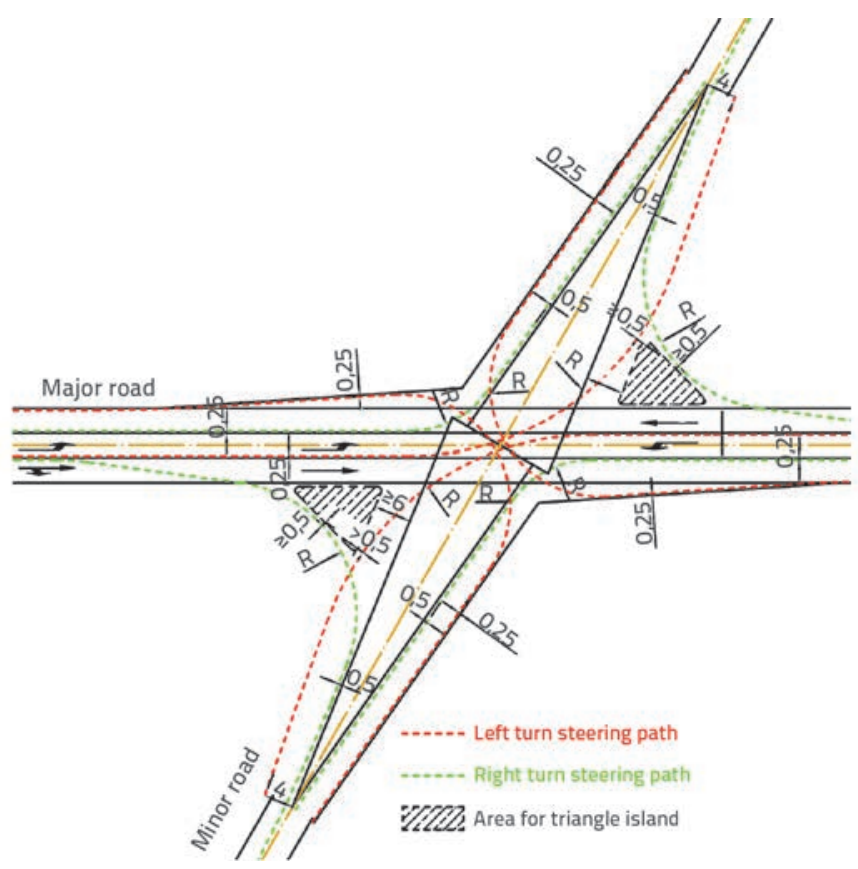

were designed between the through lane on the major road and swept paths for the left and right turns (from the major road to the minor road), with the minimum lateral safety distance of $0.5 \mathrm{~m}$.

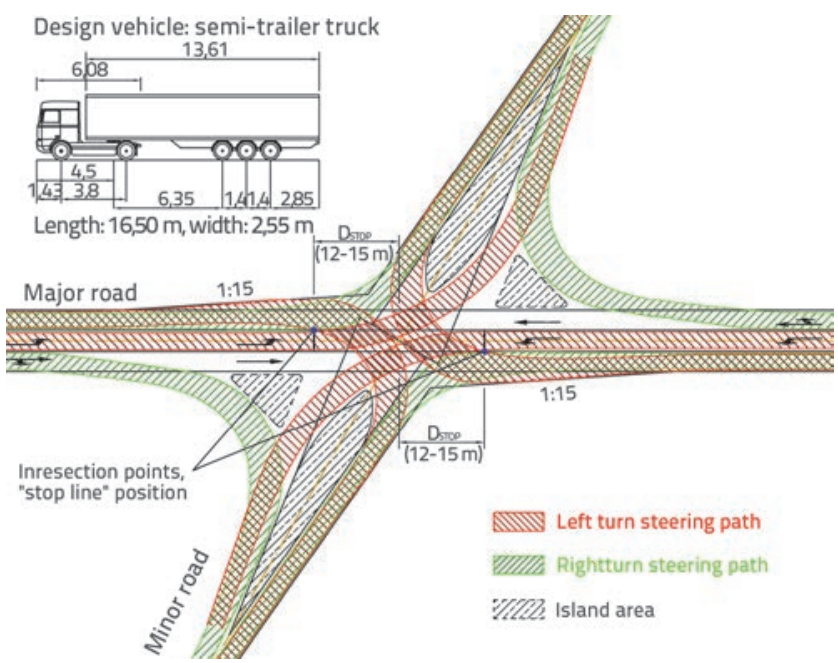

Figure 5. Swept paths analysis for design vehicle on initial schemes

Passing and lateral distances for left turn vehicles on the major road were introduced to increase intersection safety and capacity (unobstructed traffic flow). Schemes of intersections with tapered outer edges of through-traffic lanes on major roads have proven to be better than intersection schemes without the taper due to improved channelization of traffic flows [29]. Because of that the "stop line" was closer to the axes intersection point, which consequently leads to the shorter time needed for the vehicles to pass through the intersection without encroaching into the lanes intended for 
other vehicles. The position of the "stop line" was determined as an intersection point between the vehicle swept path for the left turn (from the minor to the major road) and the left turn lane edge on the major road (Figure 5). The distance between intersection points, depending on the intersection angle, ranges from 25.0 to $28.0 \mathrm{~m}$ on intersection schemes without the taper, while it ranges from 12.0 to $15.0 \mathrm{~m}$ on intersection schemes with the taper [29]. Tapered throughtraffic lane edges on the major road should serve for heavy goods (long) vehicles manoeuvring, and their use should not reduce traffic safety on the major road since vehicles on the major road can still keep driving in their original direction.

\section{Research results}

Based on the swept path analysis for the design vehicle on all $(1,240)$ intersection schemes, the intersection scheme with the following parameters $A_{1}=7.33 \mathrm{~m}, A_{2}=5.0 \mathrm{~m}, B=55.0 \mathrm{~m}, C=$ $45.0 \mathrm{~m}$ was selected as a default solution for intersection angles between 60 and $90^{\circ}$. Compared to other intersection schemes, this intersection scheme has, for most intersection angles, shorter distances (from 14.0 to $15.0 \mathrm{~m}$ ) between the "stop lines" and the axes intersection point, and it also has shorter distances (from 3.46 to $4.04 \mathrm{~m}$ ) between the tip of the nose of the central channelizing island and the through lane edge on the major road (Figure 6). Parameters of the selected intersection scheme show that lanes on the minor road are asymmetrically tapered from the road axis, the left lane at the rate of 1:7.5 and the right lane at the rate of 1:11.

Testing has shown that the selected scheme can be applied for various lane widths on major and minor roads, bearing in mind that the following combinations of lane widths can be used on the major road: $3.0-3.5-3.0,3.25-3.25-3.25$ or $3.25-$ $3.5-3.25 \mathrm{~m}$ (the central value is the width of the left turn lane and the other two values represent the width of through-traffic lanes). This scheme served for further research of intersection elements (for intersection angles of $60 \leq \alpha \leq 90^{\circ}$ ) as follows:

- traffic channelizing island on minor road legs,

- right turn roadway edge on minor road legs,

- taper and triangular channelizing island for the right turn from the major to the minor road.

Due to writing space restrictions, the recommendations provided below are limited to an optimum design of central channelizing islands and right roadway edges on intersections.

\subsection{Design of traffic channelizing island}

The traffic channelizing island is positioned on the minor road between tapered lanes (Figures 5, 6). Internal edges of the tapered lanes represent both sides of the island. Test results show that the island nose should be designed with three circular arcs $\left(\mathrm{R}_{\mathrm{MS}^{\prime}} \mathrm{R}_{\mathrm{SM}^{\prime}} \mathrm{R}=0.75 \mathrm{~m}\right)$ so that the nose offset from the major roadway edge can vary from 2.0 to 4.0 $\mathrm{m}$. The radii of circular arcs $\mathrm{R}_{\mathrm{MS}}$ and $\mathrm{R}_{\mathrm{SM}}$ were determined by testing, and are given in Table 1 in relation to intersection angles. For other intersection angles, radius can be obtained by linear interpolation between two adjacent ones given in Table 1, and this value should be rounded to the accuracy of $0.5 \mathrm{~m}$.

Table 1. Radii of circular arcs $\mathbf{R}_{\mathrm{Ms}}$ and $\mathbf{R}_{\mathrm{SM}}$

\begin{tabular}{|c|c|c|c|c|c|c|c|}
\hline$\alpha\left[^{\circ}\right]$ & $\mathbf{6 0}$ & $\mathbf{6 5}$ & $\mathbf{7 0}$ & $\mathbf{7 5}$ & $\mathbf{8 0}$ & $\mathbf{8 5}$ & $\mathbf{9 0}$ \\
\hline $\begin{array}{c}\mathbf{R}_{\mathrm{MS}} \\
{[\mathrm{m}]}\end{array}$ & 34,0 & 29,5 & 26,0 & 23,5 & 20,5 & 18,5 & 16,5 \\
\hline $\begin{array}{c}\mathbf{R}_{\mathrm{SM}} \\
{[\mathrm{m}]}\end{array}$ & $\begin{array}{c}12,5 \\
(13,0)\end{array}$ & $\begin{array}{c}14,0 \\
(14,5)\end{array}$ & $\begin{array}{c}15,0 \\
(15,5)\end{array}$ & $\begin{array}{c}16,5 \\
(17,0)\end{array}$ & $\begin{array}{c}18,5 \\
(19,0)\end{array}$ & $\begin{array}{c}20,5 \\
(21,0)\end{array}$ & $\begin{array}{c}23,0 \\
(23,5)\end{array}$ \\
\hline
\end{tabular}

The nose of the central channelizing island can be designed as follows (Figure 6):

1. design circular arc of $\mathrm{R}_{\mathrm{MS}}$ radius tangent to the left edge of left turn lane on the major road and the left edge of the island on the minor road,

2. design circular arc of $R_{S M}$ radius tangent to the right edge of the island on the minor road and the left edge of through lane on the major road,

3. round off the nose of the island by circle $0.75 \mathrm{~m}$ in radius.

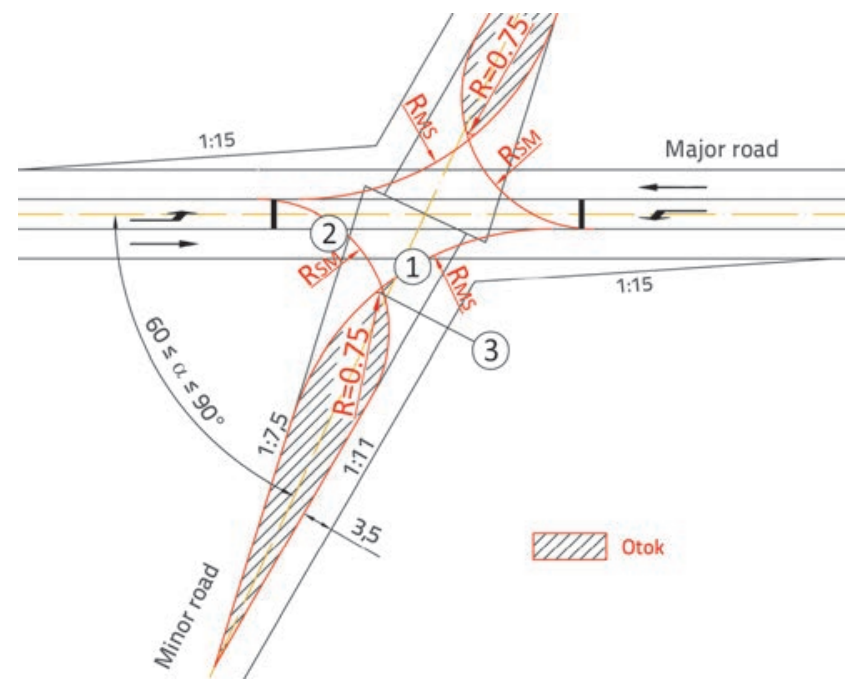

Figure 6. Traffic channelizing island nose design

According to design practice, and in line with the standard [15] and guidelines [16], channelizing islands on minor roads usually consist of the raised and marked parts, so as to enable clear channelization of traffic flows. Relevant research has shown that on the selected intersection scheme (depending on the intersection angle) the raised part of the island can be max. 30 $\mathrm{m}$ long if both ends are rounded by circular arc $0.75 \mathrm{~m}$ in radius, while the length of the marked part of the island can range from 10.0 to $15.0 \mathrm{~m}$. 


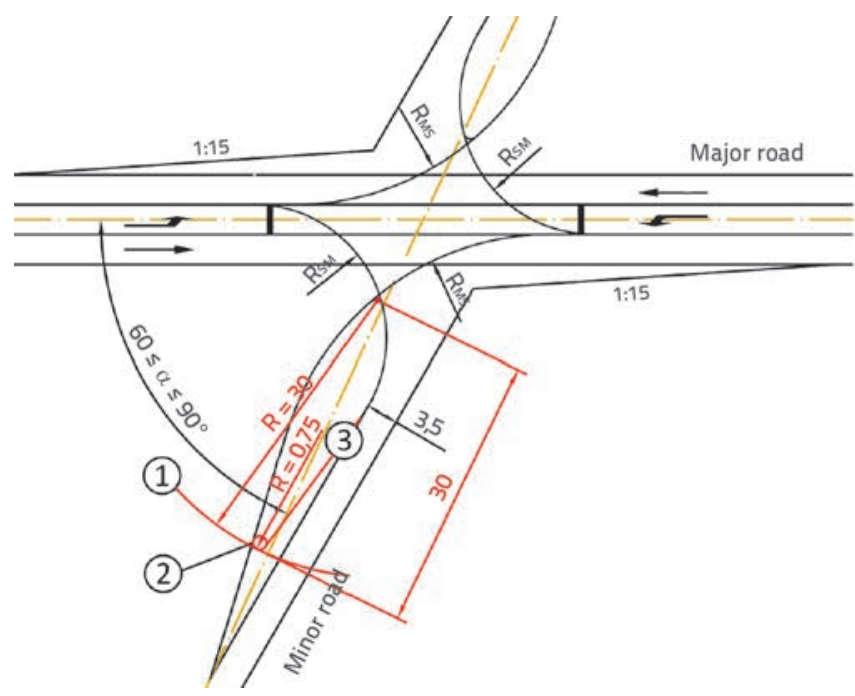

Figure 7. Design of raised part of traffic channelizing island

The raised part of the island can be designed in the following way (Figure 7):

1. design circular arc $30 \mathrm{~m}$ in radius from the nose of the island rounded off by the circular arc $(R=0.75 \mathrm{~m})$ so that it crosses the road axis and the left edge of the island,

2. design circle $0.75 \mathrm{~m}$ in radius, tangent (mutual tangent) to the circular arc from the first step and the left edge of the island,

3. design straight line tangent to the circle from the second step, and circular arc $\mathrm{R}_{\mathrm{SM}}$ in radius.

\subsection{Design of right turn roadway edge}

The right turn roadway edge design is determined on the basis of the design vehicle swept path for the left and right turns from the minor to the major road (Figure 5). Research has shown that the right turn roadway edge on minor roads should be designed in two different ways depending on intersection angle, and in

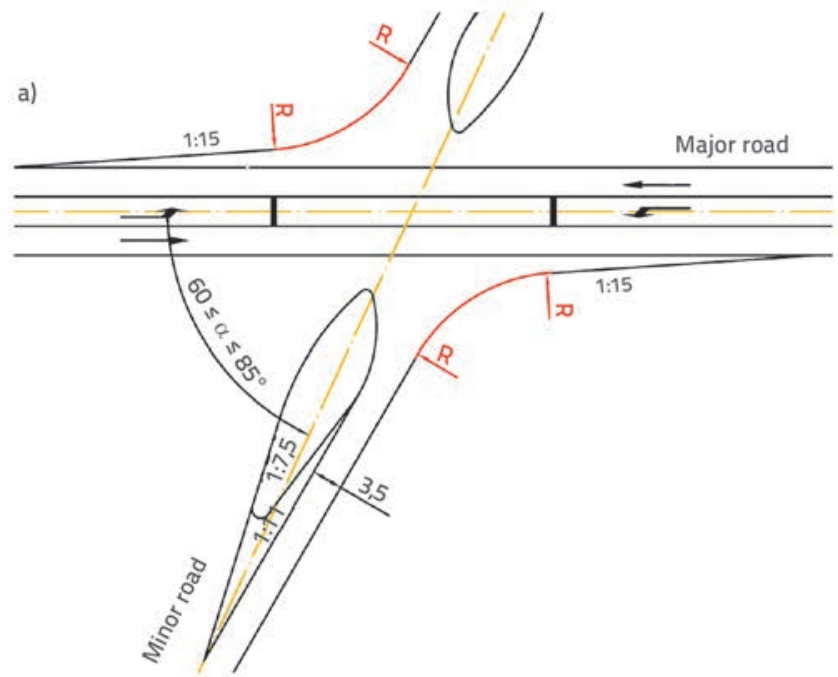

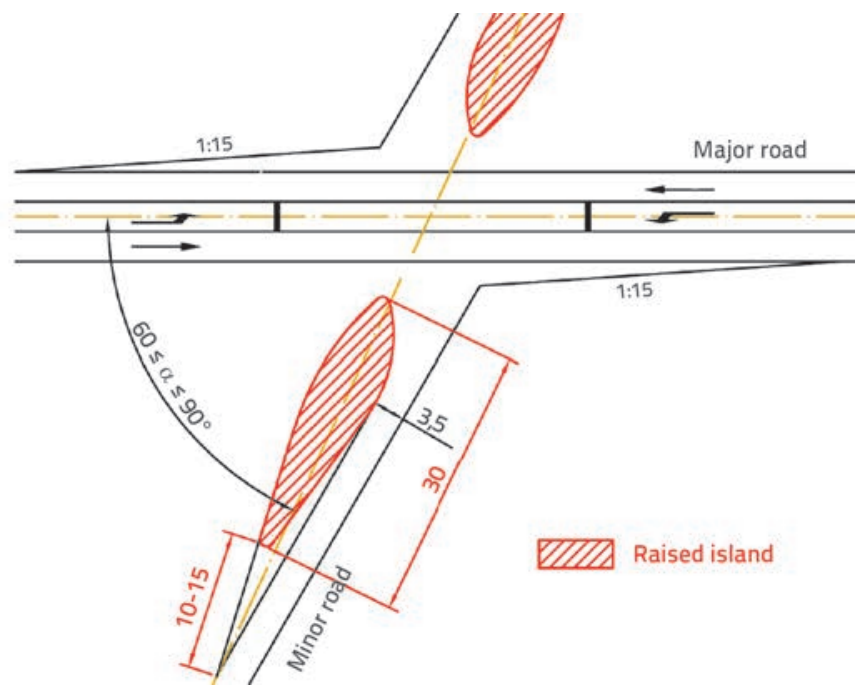

order to ensure an undisturbed flow of traffic. At intersections with the angles of $60 \leq \alpha<85^{\circ}$, the right edge should be designed with one circular arc (Figure 8a). At intersections with the angles of $85 \leq \alpha \leq 90^{\circ}$, the right edge should be designed with three circular arcs whose radii ratio amounts to $\mathrm{R}_{1}: \mathrm{R}_{2}: \mathrm{R}_{3}=$ $2: 1: 3$ (Figure 8b). In such a way, tapered outer edges (1:15) of major road through-traffic lanes have proven to be an optimal solution since they are necessary not only for the left, but also for the right turners from a minor to a major road (Figures 8, 9, 10).

Table 2. Circular arc radii for designing right turn roadway edge at intersections

\begin{tabular}{|c|c|c|c|c|c|c|c|}
\hline$\alpha\left[^{\circ}\right]$ & $\mathbf{6 0}$ & $\mathbf{6 5}$ & $\mathbf{7 0}$ & $\mathbf{7 5}$ & $\mathbf{8 0}$ & $\mathbf{8 5}$ & $\mathbf{9 0}$ \\
\hline $\mathbf{R}[\mathrm{m}]$ & 21,0 & 19,0 & 18,0 & 17,0 & 17,0 & - & - \\
\hline $\mathbf{R}_{\mathbf{2}}[\mathrm{m}]$ & - & - & - & - & - & 11,0 & 11,0 \\
\hline
\end{tabular}

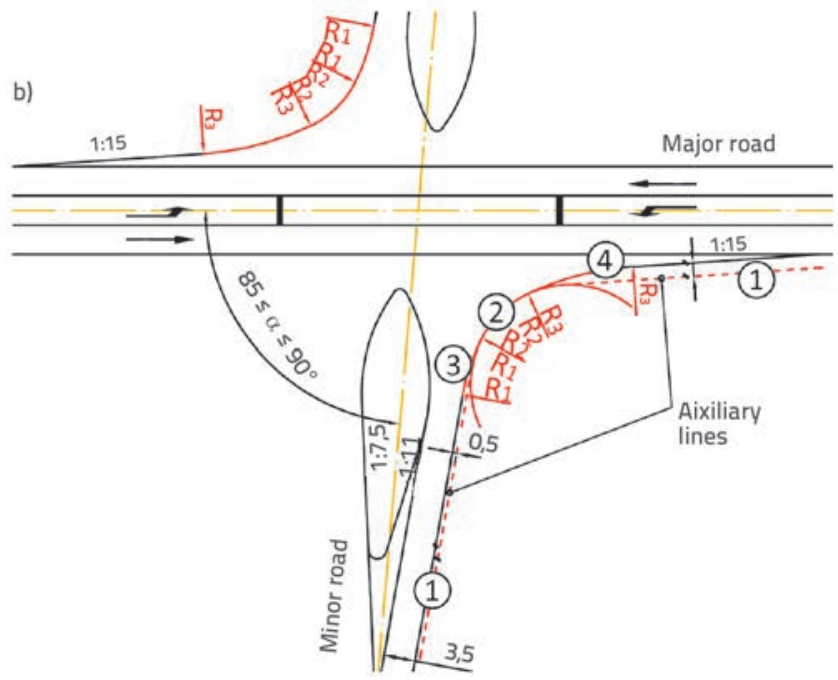

Figure 8. a) Right turn roadway edge design for angles $60 \leq \alpha<85^{\circ}$ b) Right turn roadway edge design for angles $85 \leq \alpha \leq 90^{\circ}$ 
Circular arc radii $\mathrm{R}$ and $\mathrm{R}_{2}$ are given in Table 2 in relation to intersection angles. For angles $80<\alpha<85^{\circ}$, the circular arc radius should be similar to that adopted for the angle of $80^{\circ}$. For other intersection angles, the radii can be determined by linear interpolation between two adjacent radii, and should be rounded to the accuracy of $0.5 \mathrm{~m}$.

The right turn roadway edge for the angles $85 \leq \alpha \leq 90^{\circ}$ can be designed as follows (Figure 8b):

1. design two auxiliary lines, the first one parallel to the right lane edge of the minor road, at the distance of $0.5 \mathrm{~m}$, and the second one parallel to the taper (1:15) on the major road, at the distance of $1.5 \mathrm{~m}$

2. design circular arc $R_{2}$ in radius (Table 2 ) tangent to the auxiliary lines from the first step

3. design circular arc $R_{1}$ in radius tangent (mutual tangent) to the circular arc of $R_{2}$ radius and the right lane edge of the minor road

4. design circular arc $\mathrm{R}_{3}$ in radius tangent to the circular arc (mutual tangent) of $R_{2}$ radius and the taper (1:15) on the major road.

\subsection{Evaluation of new design procedure}

Evaluation of the new design procedure was conducted on two theoretical four-leg intersections with intersection angles that were not directly included in the previous testing. For the purpose of evaluation, intersection elements (roadway edges, islands) were designed in accordance with the new procedure described in Sections 4.1 and 4.2 for intersection angles 62 and $82^{\circ}$ (Figures 9, 10), for the $16.5 \mathrm{~m}$ long semi-trailer truck, and for the major road lane widths of $3.25-3.25-3.25 \mathrm{~m}$.

Figure 9 shows a channelized four-leg at-grade intersection, designed for the angle of $62^{\circ}$ on the basis of the following input data:

- intersection scheme was drawn based on the data from Section 4,

- radii $R_{M S}=32.0 \mathrm{~m}$ and $R_{S M}=13.5 \mathrm{~m}$ were selected for the design of channelizing islands by interpolation from Table 1 (passing distance is $1.0 \mathrm{~m}$ for the left turn vehicles),

- circular arc radius $\mathrm{R}=21.0 \mathrm{~m}$ was selected from Table 2 for the design of right turn roadway edges on minor roads.

Figure 10 shows a channelized four-leg at-grade intersection, designed for the angle of $82^{\circ}$ on the basis of the following input data:

- intersection scheme was drawn based on the data from Section 4,

- radii $R_{M S}=19.5 m$ and $R_{S M}=19.5 m$ were selected for the design of channelizing islands by interpolation from Table 1 (passing distance is $1.0 \mathrm{~m}$ for the left turn vehicles),

- circular arc radius $\mathrm{R}=17.0 \mathrm{~m}$ was selected from Table 2 for the design of right turn roadway edge on minor roads.

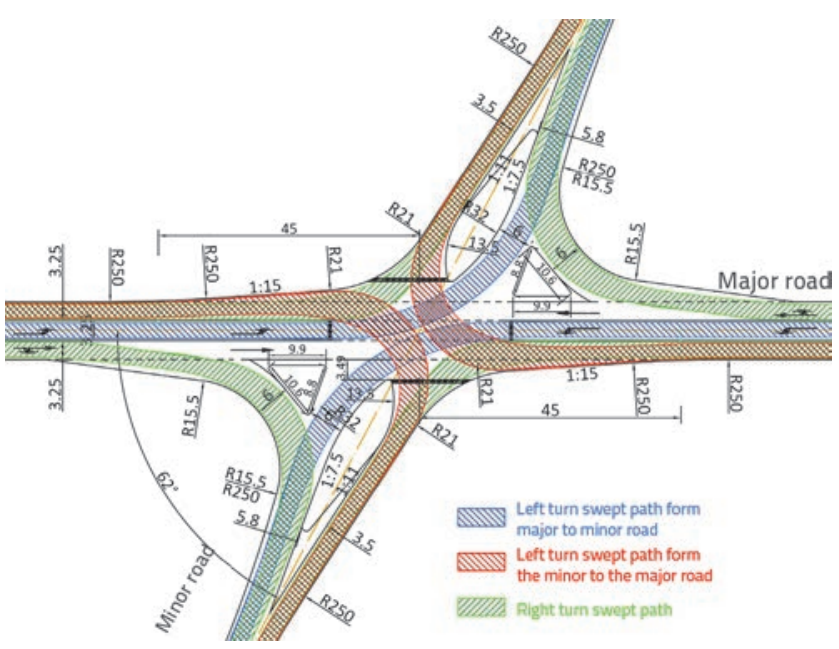

Figure 9. Channelized four-leg at-grade intersection with intersection angle of $62^{\circ}$

The swept path analysis performed on the mentioned intersections (Figures 9, 10) revealed that the new procedure for the design of intersection elements ensures an undisturbed traffic flow of the design vehicle, respecting the predicted protective lateral clearance of $0.5 \mathrm{~m}$ along the raised islands and $0.25 \mathrm{~m}$ along the roadway edges.

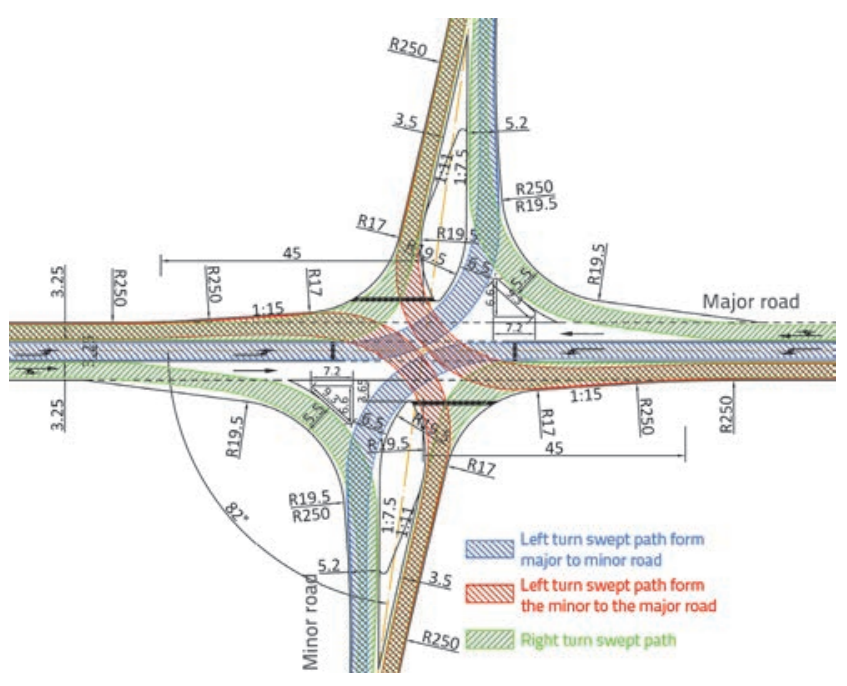

Figure 10. Channelized four-leg at-grade intersection with intersection angle of $82^{\circ}$

After the swept path analysis confirmed that the default scheme and the new procedure are appropriate, the evaluation has been extended to include four-leg intersections with different intersection angles on both minor road legs. Test results (Table 3 ) revealed that almost all combinations of intersection angles are possible. One combination for the intersection angles of 65 and $85^{\circ}$ is presented in Figure 11. 
Table 3. Possible combinations of intersection angles

\begin{tabular}{|c|c|c|c|c|c|c|c|}
\hline$\alpha\left[{ }^{\circ}\right]$ & 60 & 65 & 70 & 75 & 80 & 85 & 90 \\
\hline 60 & + & & & & & & \\
\hline 65 & + & + & & & & & \\
\hline 70 & + & + & + & & & & \\
\hline 75 & + & + & + & + & & & \\
\hline 80 & + & + & + & + & + & & + \\
\hline 85 & - & + & + & + & + & + & + \\
\hline 90 & - & - & + & + & + & + & \\
\hline $\begin{array}{l}\text { + possible combination } \\
\text { - impossible combination }\end{array}$
\end{tabular}

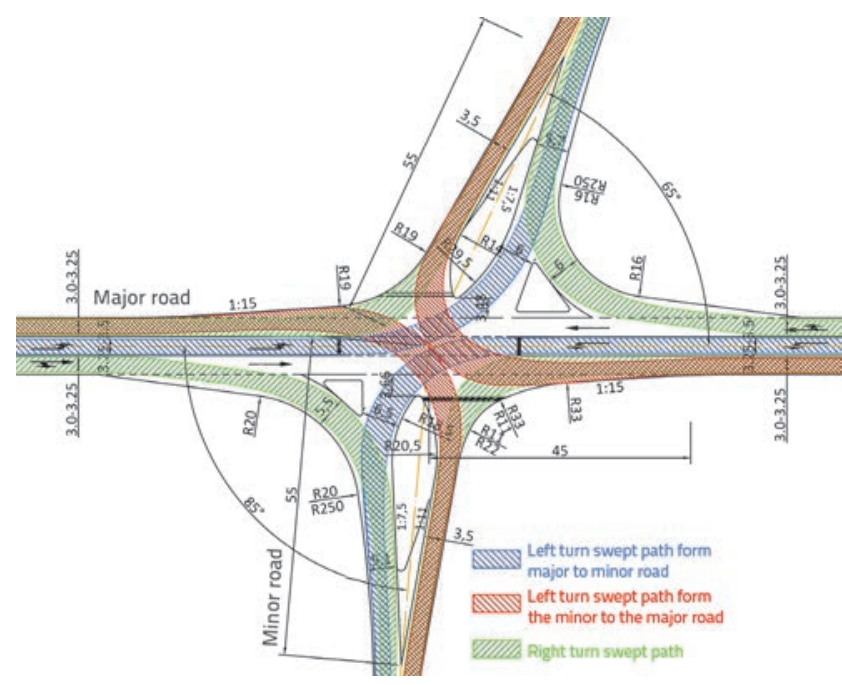

Figure 11. Channelized four-leg at-grade intersection with intersection angles of 65 and $85^{\circ}$

\section{Discussion}

A proper-quality geometric design of intersections is the basis for safe and undisturbed operation of traffic, and for ensuring an appropriate capacity of such facilities. This study is dedicated to the geometric design of channelized four-leg at-grade intersections, i.e. to the changes in the form of the intersection design elements (islands, roadway edges) so as to take into account different intersection angles. In addition, this study is also aimed at changing the current (highly iterative) procedure of designing intersections the goal being to simplify and accelerate current procedures.

If four-leg channelized intersections are designed according to the current standard [15] or guidelines [16-18], which are primarily intended for the design of three-leg intersections, many iterations may be necessary (i.e. the process is time-consuming), which could ultimately lead to inconsistent solutions. This study contributes to consistency of intersection design by providing designers with a new design procedure in which minor road axis realignments, and subsequent swept path analysis, are not required. The efficiency of intersections designed according to the new procedure (Section 4) is reflected in a smooth movement of the design vehicle through the intersections. Vehicles that are in the opposite legs waiting to turn left do not have to wait to see which one will pass the intersection first (Figures 9, 10). Unlike the currently used approach, the modifications of outer roadway edges on the major road (taper with the ratio of 1:15) in the intersection zone enables vehicles to avoid encroachment into the lanes intended for other drivers, while the passing time of vehicles turning left is shorter, since the "stop line" is closer to the road axes intersection point. The results of this study also show that it is possible to design an intersection with legs having different intersection angels (Table 3 , Figure 11). That is why the installation of traffic lights would be possible at such intersections without the need to undertake additional rehabilitation work.

Practically, no similar studies have been made in this area of research. However, there are many design manuals or guides $[13,30-32]$ that are based on the experience accumulated in the design of channelized at-grade intersections in different states of the US. Most of the manuals have separate procedures for the design of all elements of the intersection (roadway edges, islands, additional traffic lanes) and this mainly for the intersection angle of $90^{\circ}$. Changing the form of the elements depending on the angle of intersection is defined solely in [30] and only for the right roadway edge at the right turn from a minor to a major road. The applicability of the US manuals in Europe is questionable because the design vehicles (especially heavy goods vehicles) in Europe are of different dimensions.

Although the new design procedure has been verified, the main drawback of this study is that it was conducted on theoretical examples of intersections. Therefore, additional tests should be conducted on real examples to detect possible shortcomings and make corrections if needed. Accidents can often occur on four-leg unsignalized channelized intersections because of the numerous vehicle operations. One of the main cause of accidents on such intersections is speeding. Appropriate research has been conducted in order to reduce the driver speed on intersections $[33,34]$ and the results have shown which type of signalization is the most effective for reducing the speed. This research results should be considered while testing real intersection examples.

\section{Conclusion}

The research results have shown that it is possible to define a new procedure for the design of four-leg channelized intersections which provides, from the very start, exact dimensions of intersection elements (islands, roadway edges). The new procedure also enables design of intersections with different angles of intersection without the need for realigning the minor road axis. Intersection design based on this new procedure should be reliable 
because the procedure has been verified on intersection examples with intersection angles that have not been directly included in the research.

Because of consistency in the design of intersection elements, the results of this study should help designers in their work

\section{REFERENCES}

[1] Ye, X., Pendyala, R.M.: Washington, S. P.; Konduri, K.; Oh. J.. A Simultaneous Equations Model of Crash Frequency by Collision Type for Rural Intersections. Safety Science, 47 (2009) 3, pp. $443-$ 452, https://doi.org/10.1016/j.ssci.2008.06.007

[2] Abdel-Aty, M., Haleem, K.: Analyzing Angle Crashes at Unsignalized Intersections Using Machine Learning Techniques. Accident Analysis and Prevention, 43 (2011) 1, pp. 461-470, https://doi. org/10.1016/j.aap.2010.10.002

[3] Wang, Y.G., Bai, H., Xiang, W.S.: Traffic Safety Performance Assessment and Multivariate Treatments for Intersection Locations. The Baltic Journal of Road and Bridge Engineering, 6 (2011) 1, pp. 30-38,. https://doi.org/10.3846/bjrbe.2011.05

[4] Roge, J., Pebayle, T., Lambilliotte, E.: Influence of age, speed and duration of monotonous driving task in traffic on the driver's useful visual field. Vision Research, 44 (2004) 23, pp. 2737-2744, https://doi.org/10.1016/j.visres.2004.05.026

[5] Oxley, J., Fildes, B., Corben, B., Langford, J.: Intersection design for older drivers. Transportation Research Part F, Accident Research Centre, Monash University, Melbourne, Australia, 9 (2006), pp. 335-346.

[6] Whelan, M., Langford, J., Oxley, J., Koppel, S., Charlton, J.: The elderly and Mobility: A Review of the Literature. Report 255, Monash University Accident Research Centre, Clayton, Victoria, Australia, pp. 73-84, 2006.

[7] Dukic, T., Broberg, T.: Older drivers' visual search behaviour at intersections. Transportation Research Part F-Traffic Psychology and Behaviour, 15 (2012) 4, pp 462-470, https://doi.org/10.1016/j. trf.2011.10.001

[8] Rakotonirainy, A, Steinhardt, D, Delhomme, P.: Older drivers' crashes in Queensland, Australia. Accident Analysis and Prevention, 48 (2012) SI, pp. 423-429, https://doi.org/10.1016/j. aap.2012.02.016

[9] Giuffrè, O., Guerrieri, M., Granà, A.: Turbo-roundabout General Design Criteria and Functional Principles: Case Studies from Real World. Proceedings of the $4^{\text {th }}$ International Symposium on Highway Geometric Design, (eds. Harwood, D.W., García García, A.), Universidad Politecnica de Valencia, 2010.

[10] Dragčević, V., Korlaet, Ž., Rukavina, T., Lakušić, S.: Threeleg Intersection at-Grade - The Right Edge Forming Test. $3^{\text {rd }}$ International Symposium on Highway Geometric Design June 29 - July 1 2005. Transportation Research Board, Chicago, Illinois.

[11] Autey, J., Sayed, T., Zaki, M.H.: Safety evaluation of right-turn smart channels using automated traffic conflict analysis. Accident Analysis and Prevention, 45 (2012), pp. 120-130, https://doi. org/10.1016/j.aap.2011.11.015

[12] Persaud, B., Lyon C., Gross, F., Eccles, K.: Safety Evaluation of Offset Improvements for Left-Turn Lanes. Proceedings of the $4^{\text {th }}$ International Symposium on Highway Geometric Design, (eds. Harwood, D.W., García García, A.), Universidad Politecnica de Valencia, 2010, https://doi.org/10.3141/2171-05 and could be incorporated in the intersection design software programs.

Future research should focus on the application of the new procedure on other types of intersections, such as roundabouts and turbo roundabouts exhibiting various intersection angles.
[13] Left-Turn Accommodations at Unsignalized Intersections. National Cooperative Highway Research Program (NCHRP), Report 745. Transportation Research Board. Washington, D.C. 2013.

[14] Al-Kaisy, A., Roefaro, S. Channelized Right-Turn Lanes at Signalized Intersections: A Review of Practice. Proceedings of the $4^{\text {th }}$ International Symposium on Highway Geometric Design, (eds. Harwood, D.W., García García, A.), Universidad Politecnica de Valencia, 2010.

[15] HRN U.C4.050: Projektiranje i građenje cesta, površinski čvorovi, tehnički uvjeti, 1990.

[16] Richtlinien für die Anlage von Landstraßen (RAL), Ausgabe 2012. Forschungsgesellschaft für Straßen- und Verkehrswesen (FGSV Verlag), Köln 2012.

[17] Vereinigung Schwiezerischer Strassenfachleute (VSS), Schweizer Norm (SN 640262), Zürich, 1999.

[18] Plangleiche Knoten - Kreuzungen, T-Kreuzungen, Österreichische Forschungsgesellschaft Straße-Schiene-Verkehr (FSV), (RVS 03.05.12), Wien, 2007

[19] A Policy on Geometric Design of Highways and Streets 2004. American Association of State Highway and Transportation Officials.

[20] Garcia, A.: Lateral Vision Angles and Skewed Intersections Design. Proceedings of $3^{\text {rd }}$ International Symposium on Highway Geometric Design. Chicago, June 29-July 1, 2005.

[21] Garcia, A., Belda-Esplugues, E.: Lateral Vision Angles in Roadway Geometric Design. Journal of Transportation Engineering, 133 (2007) 12, pp. 654-662, https://doi.org/10.1061/(ASCE)0733947X(2007)133:12(654)

[22] Garcia, A., Libreros, C.L.: Safety Effect of the Skew Angle in Right Turn Maneuvers. 3rd Urban Street Symposium June 24 - 27, 2007. Seatlle, Washington.

[23] Stančerić, I., Korlaet, Ž., Dragčević, V.: Sight distance tests at road intersections with unfavourable angles. Road and Rail Infrastructure II, Proceedings of the $2^{\text {nd }}$ International Conference on Road and Rail Infrastructure - CETRA 2012 (ed. Lakusic, S.), Faculty of Civil Engineering, University of Zagreb, 2012. pp. 1117-1127.

[24] Dragčević, V., Korlaet, Ž., Stančerić, I.: Methods for setting road vehicle movement trajectories. The Baltic Journal of Road and Bridge Engineering, 3 (2008) 2, pp. 57-64, https://doi. org/10.3846/1822-427X.2008.3.57-64

[25] Korlaet, Ž., Dragčević, V., Stančerić, I.: Designing Criteria of Acute Angle Four-Leg Intersection At-Grade. Proceedings of the $4^{\text {th }}$ International Symposium on Highway Geometric Design, (eds. Harwood, D.W., García García, A.), Universidad Politecnica de Valencia, 2010.

[26] Isler, R.B., Parsonson, B.S., Hansson, G.J.: Age related effects of restricted head movements on the useful field of view of drivers. Accident Analysis and Prevention, 29 (1997) 6, pp. 793-801, https://doi.org/10.1016/S0001-4575(97)00048-1 
[27] Commission Directive 2009/113/EC of 25 August 2009 amending Directive 2006/126/EC of the European Parliament and of the Council on driving licences.

[28] Directive 2002/7/EC of the European Parliament and of the Council of 18 February 2002 amending Council Directive 96/53/ EC laying down for certain road vehicles circulating within the Community the maximum authorised dimensions in national and international traffic and the maximum authorised weights in international traffic, 9.3.2002.

[29] Highway Department Project Development \& Design Guide ch. 6: Intersection Design. MADOT, Massachusetts Department of Transportation - Highway Division, 2006. http://www.mhd.state. ma.us/downloads/designGuide/CH_6_a.pdf

[30] Florida Intersection Design Guide. Florida DOT, 2007. http://www. fdot.gov/roadway/fidg-manual/fidg2007.pdf
[31] Facilities Development Manual, Chapter 11, Design Section 25, Intersections at Grade. Wisconsin Department of Transportation, June 24, 2016. http://wisconsindot.gov/rdwy/fdm/fd-11-25.pdf

[32] Gross, F., Jagannathan, R., Hughes, W.: Two Low-Cost Safety Concepts for Two-Way, Stop-Controlled Intersections in Rural Areas. Transportation Research Record 2092, pp. 11-18, 2009, https://doi.org/10.3141/2092-02

[33] Montella, A., Aria M., D'Ambrosio, A., Galante, F., Mauriello, F., Pernetti, M.: Simulator evaluation of drivers' speed, deceleration and lateral position at rural intersections in relation to different perceptual cues. Accident Analysis and Prevention, 43 (2011), pp. 2072-2084, https://doi.org/10.1016/j.aap.2011.05.030 